\title{
PUBLIC FINANCE - THE IMPACT OF RECREATIONAL VOUCHERS ON PUBLIC FINANCES AND SUPPORT FOR DOMESTIC TOURISM*
}

\author{
Peter DORČÁK ${ }^{1}$ Peter MARKOVIČ² $\quad$ Ingrid DORČÁKOVÁ ${ }^{3} \quad$ Martin NOVYSEDLÁK ${ }^{4}$
}

\begin{abstract}
The paper provides information on the importance of introducing an allowance for recreation in the Slovak Republic. The mentioned allowance has become such a new expense for employers, i.e. for the state and the private sector, after the approval of the National Council of the Slovak Republic from 1 January 2019, as an amendment to the Tourism Promotion Act. Paper outlines the goal, the motive for adopting the amendment to the Act on Tourism in the form of an allowance for recreation and describes the various conditions necessary for the use of the allowance but also various possibilities how this allowance can be used by the employees. At the same time, it specifies the impact of the allowance for recreation as an expense in one of the state institutions, namely the education sector, together with proposed resolution of covering the costs related to it that were not allocated in the budget of University of Economics in Bratislava. At the end of the paper the results of the survey on recreational allowance from the perspective of both employees and employers are shown, providing further details on opinions about the recreational allowance, awareness about the details and plans of implementations in companies. It could be concluded that further dissemination of information about the allowance for recreation is still necessary.
\end{abstract}

Keywords: Public finance, domestic tourism, state support, recreational vouchers

\section{Introduction}

The topic of public finances is well known on a daily basis. This is because public finances are an important part of every state, as they ensure the country's functioning. Every citizen should be aware of the revenue and expenditure that constitutes the state budget. Public finances affect almost every person, whether directly or indirectly, for example, in the form of taxes that are part of them, and we pay them as working employees, or we come in contact with them at regular purchases. They are also included in public spending, which in part is directed at wages of employees in the state and public sectors. Thus, we can say that on the one hand we contribute to the state budget and public budgets, in the form of taxes, and on the other hand, public goods and public administration of the state apparatus are provided from the state and public budgets. Therefore, it is up to the state how it spends public funds, but at the same time it also manages the private sector through laws and coordinates its incomes and expenditures. 
In addition to the incentive to motivate the population to spend their holidays in Slovakia, the law, through the introduced tourism financing instruments and allowance for recreation, also responds to the fact that hotel-type accommodation facilities in Slovakia are among the lowest rates of occupancy among European countries. According to available statistics, in the weakest seasons, the use of these facilities is only around $20 \%$, and rarely exceeds $40 \%$. This, while maintaining the status quo, poses a threat of redundancies for workers working in accommodation services and services related to these services. The introduction of the proposed measures is expected to have a positive impact on tourism businesses, with increased demand for accommodation and related services, the development of marginalized regions and the creation of new jobs in tourism and related industries, increased traffic and awareness of the domestic tourism.

\subsection{Defining Public Finances on National Level and in The World}

Most of the world's economies operate on a combination of a market economy, an economy that is affected by market mechanisms, combined with certain state interventions that help to guide and correct market developments. The reasons why economies operate like this are market failures that the market mechanism alone is unable to solve. These are in particular imperfect competition, the existence of monopolies, market externalities and unemployment (Schultzová et. al., 2007: 9).

The existence of public finances is also important because most of the world's economies are based on a market economy. And it is important to coordinate the market economy by interventions by the state, where the public sector is funded by public finances.

The definition of the public sector shows that public finances are one of its important components. One of the first to define public finances was Adam Smith, who applied a household management system to them. Later, R. A. Musgrave defined the concept of public finance as a complex, with public revenue and public spending processes at its centre. By contrast, Hamerníková defines public finances from a narrower and broader perspective. In a broader sense, public finances are a tool through which public policy is implemented. In the narrower sense, under public finances are meant the monetary relations that arise in connection with the creation, distribution and use of funds linked to the activities of public institutions. (Sivák, 2007: 56-57).

Public Finance is the branch of economics that studies the taxing and spending activities of government. The term is something of a misnomer, because the fundamental issues are not financial (that is, relating to money). Rather, the key problems relate to the use of real resources. For this reason, some practitioners prefer the label public sector economics or simply public economics. Public finance encompasses both positive and normative analysis. Positive analysis deals with issues of cause and effect, for example, "If the government cuts the tax rate on gasoline, what will be the effect on gasoline consumption?" Normative analysis deals with ethical issues, for example, "Is it fairer to tax income or consumption?"

Modern public finance focuses on the microeconomic functions of government, how the government does and should affect the allocation of resources and the distribution of income. For the most part, the macroeconomic functions of government - the use of taxing, spending, and monetary policies to affect the overall level of unemployment and the price level - are covered in other fields (Rosen, 2004: 252). 
When examining public finances, it is also necessary to be familiar with the environment, and therefore we examine it from a macroeconomic and microeconomic perspective. The macroeconomic approach examines the impact of public finances on core macroeconomic variables, such as GDP, as public expenditure, as one of the components of public finances, is one of the main components of GDP, as opposed to a microeconomic approach that examines the impact of public revenues and spending on economic behaviour.

Public finances are used to finance the public sector but can also be seen as one of the economic sciences. The subject of its research are the finances of the state, organizations and the population (Gruber, 2011: 3).

The balance of public finances is influenced by economic, political, organizational and technical factors (Rosen, 1992: 290).

\subsection{Public Finances in The Form of An Allowance to Recreation in Slovakia}

Slovakia has good conditions for tourism development. The most important factors are the first-class natural conditions - nature reserves, a number of mountains and water areas, and also numerous historical monuments.

In October 2018, the National Council of the Slovak Republic approved, by a number of amendments, allowances for recreation and so-called "recreational vouchers". Recreation allowances and recreational vouchers have become a reality since $1^{\text {st }}$ of January 2019, when changes to approved regulations came into effect.

Companies have so far provided recreation allowances only within the framework of a package of above-standard benefits paid from the social fund or from profits. According to statistics, the benefits for recreation were not so popular. And even when the recreation allowance was used, more than $59 \%$ of the value was used for foreign tours from travel agencies.

Allowance for home recreation was used by only $4 \%$ of employees in the average value of 210 euro. Other employees use benefit budgets for other benefits such as health, sports, culture and foreign holidays. Approximately $60 \%$ of employees from companies with more than 49 employees will start using the home recreation allowance after the introduction of the vouchers. The remaining $40 \%$ will not use recreational vouchers because they either do not work in the company for more than 2 years or will not be interested in recreational vouchers.

Changes from 1 January 2019 should increase the incentive for economically active residents and their immediate family members to spend their holidays in the Slovak Republic under financially favourable conditions.

The introduction of this new institute expects a positive impact especially on economically active inhabitants of the Slovak Republic achieving lower disposable income, who could not afford even one recreation per year. These residents, including their closest family members, should thus be able to afford at least one recreation per year needed to regenerate their physical and mental strength and improve their quality of life. 


\subsubsection{Definition of The Law}

Amended Act no. 347/2018 of Collection of laws with effect from 1st of January 2019 amends and supplements Act no. 91/2010 Coll. on promoting tourism and modifies certain laws.

The aim of the amendment is to support domestic tourism through the introduction of new financing instruments for tourism development, the introduction of a new institute - an allowance to employee recreation, into Act no. 311/2001 Coll. of the Labour Code, as amended (hereinafter referred to as the "Labour Code"), by extending the application of tax expenditures for selfemployed persons - taxpayers with income pursuant to $\S 6$ section 1 and 2 of Act no. 595/2003 Coll. on Income Tax, as amended (hereinafter referred to as the "Income Tax Act") - for recreation expenses.

The allowance for recreation of employees was introduced into the Labour Code, because there is currently no targeted systemic tool to support domestic tourism in the Slovak Republic aimed at economically active population. States where a similar support system is already in place (France, Hungary and Italy) show the highest domestic participation on domestic private recreation trips, confirming the effectiveness of this domestic tourism support system. On the contrary, the results of European Commission surveys of EU citizens' preferences for tourism from 2015 show, that among the EU countries in 2014, only 33\% of vacationing Slovaks preferred domestic holiday over holidays abroad. At the same time, approximately half of these recreants in Slovakia did not look for typical seaside destinations, but for destinations for which the Slovak Republic also has very good conditions (nature, wellness, gastronomy, culture, sport, etc.).

One of the regulations, which, together with the Labour Code, was amended due to contributions to recreation, was Act no. 595/2003 Coll. on Income Tax. From the employee's point of view, the recreation allowance provided to the employee by his employer will be exempt from income tax.

This means that the amount that the employer provides to the employee as a recreational allowance will not be taxed, it will be a net income and the employee, and the employer will not pay health and social insurance from the allowance.

For the employer, the recreation allowance is a tax expense that will reduce his income tax base. Therefore, the recreation allowances provided in sum of more than $55 \%$ of eligible expenditure and more than $€ 275$ per year will no longer be a tax expense for the employer.

\subsubsection{Conditions of Recreational Vouchers}

\section{Conditions for the compulsory provision of a recreation allowance for the employer:}

The employer is obliged to provide a recreation allowance only under the following three conditions:

- the employer employs more than 49 employees (the condition on the employer's side is not assessed on the date of beginning of the recreation, but the average number of employees employed in the previous calendar year is decisive);

- the employee's employment relationship with the employer lasts continuously for at least 24 months and

- the employee will apply for the allowance. 
According to the Labour Code, employers employing up to 49 employees ( 1 - 49 employees) have the possibility to provide their employees with a recreation allowance under the same conditions and to the same extent as employers employing 50 or more employees are obliged to. Thus, for employers with a staff of 49 or less, the provision of recreation allowances is voluntary.

\section{Conditions for entitlement to a recreation allowance for an employee:}

- the employee must have an employment relationship with the employer for a continuous period of at least 24 months (contractors of services are not entitled)

- an employee can apply for a recreation allowance at only one employer per calendar year,

- the fulfilment of the conditions for granting an allowance for recreation is assessed on the day of the beginning of the recreation.

\section{Recreation allowance amount:}

The recreation allowance is 55\% of eligible expenditure, but not more than 275 euros per calendar year.

\section{Method of providing the allowance for recreation:}

- upon presentation of accounting documents - the employee undergoes a recreational stay; pays for his stay from their own funds; saves the accounting documentation form the stay = invoices, which he/she delivers to his employer within 30 days from the last day of recreation; employer then reimburses him $55 \%$ of the expenses, however the maximum amount of reimbursement is 175 euro. (provided that expenditures were eligible),

Invoice that is provided to the employer:

- must be issued exclusively by the accommodation facility located in the SR

- must include the name of the employee

- must include the price per stay

- must include the date of stay

- must be for at least 2 or more nights, or for a package for at least 2 nights stay.

- In the form of a recreation voucher - this decision is left to the choice of employer. According to the explanatory report to the amendment to the Act on Promotion of Tourism, this system is managed similarly as the system of catering support through meal vouchers. The system foresees the use of the already established network of entities operating in the market for meal vouchers, while the state will not need to build any additional payment systems or organizational structures. The recreation voucher has in terms of introduced Act $\S 27$ a of the Act on Promotion of Tourism fixed validity until the end of the calendar year in which it was issued. 


\section{Possibilities of using the allowance for recreation:}

- tourism services related to accommodation for at least two overnight stays in the Slovak Republic

- residential package containing accommodation for at least two overnight stays and catering services or other services related to recreation in the Slovak Republic,

- accommodation for at least two overnight stays in the Slovak Republic, which may include catering services,

- organized multi-day activities and recovery events during school holidays in the Slovak Republic for a child of an employee attending elementary school or one of the first four years of gymnasium with eight-year education plan or another child living with an employee in a common household (these can be children's summer camps as well as multi-day children's camps, where the parent brings the child in the morning and picks it up in the afternoon).

\subsubsection{Entitlement to Allowance for Recreation in State and Public Administration with An Emphasis on Education}

The allowance for recreation in the scope and under the conditions laid down by the Labour Code also includes civil servants, members of the Police Corps, members of the Slovak Information Service, members of the National Security Office, members of the Prison and Judicial Corps, customs officers, members of the Fire and Rescue Service, members of the Mountain Rescue Service, professional soldiers and employees working in the public interest.

Schools and school facilities do not have funds for recreation allowances of their employees in their budgets. Representatives of the Ministry of Finance of the Slovak Republic, the Ministry of Education, Science, Research and Sport of the Slovak Republic and the Chairman of the National Council of the Slovak Republic were asked to solve this problem.

For this reason, the Ministry of Education is preparing a calculation of the financial impact of recreational allowances for school staff in the transferred state administration and for higher education institutions and directly managed organizations that will be submitted to the Ministry of Finance. In the state budget, a reserve of 400 million euro is created for legislative changes in 2019.

It is therefore important that the schools and educational establishments concerned receive funding to contribute to recreation in the form of surplus-purpose funding. The chairman of the National Council of the Slovak Republic perceives this request positively and said that the finances for this purpose will be redistributed from the state budget by the end of April 2019.

The subsidy is intended for employees of the state and public administration, which also includes education employees. In addition, negotiations were held at the highest level with a representative of the Government of the Slovak Republic and the Confederation of Trade Unions of the Slovak Republic.

The University of Economics in Bratislava (EUBA) has a budget of $€ 12,000,000$ for 2019. It expects $€ 2,000,000$ from business activities. $A € 300,000$ reserve was created for the recreation allowances and the EUBA asked the government to pay it in the form of a special-purpose subsidy. 


\subsubsection{Survey on Recreational Vouchers}

A total of 2,723 employees and 355 employers participated in the survey, which ran from 11 to 13 January 2019.

\section{From a total of 2,723 employees:}

Figure 1. Have you heard of/ were interested in allowance for recreation from your employer?

\section{Počuli ste / zaujímali ste sa o príspevok na rekreáciu od zamestnávatela?}

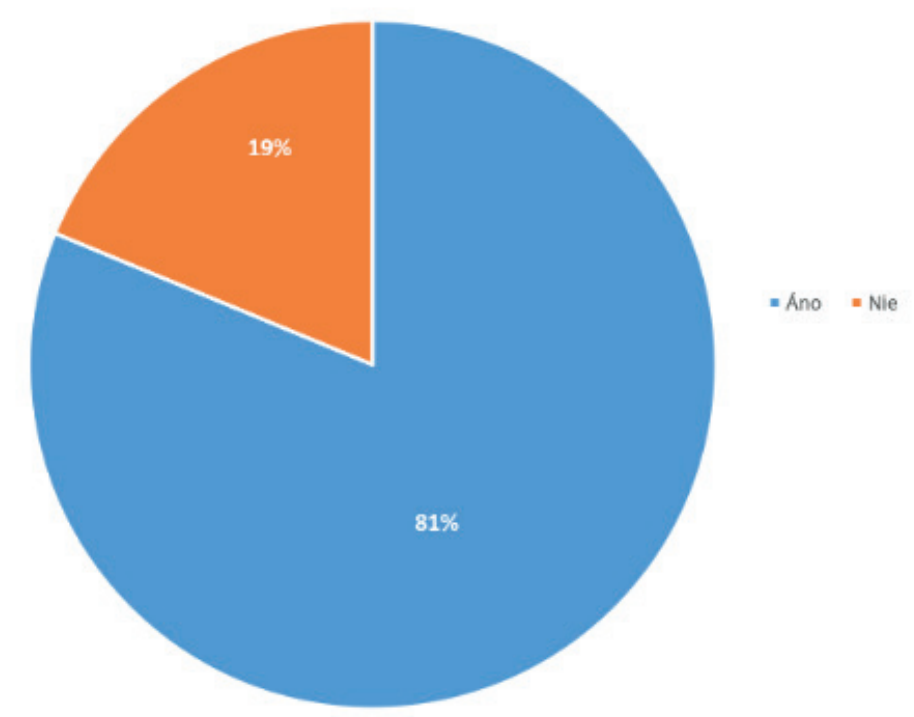

Source: ZDROJ

$81 \%$ of employees have already heard of or were interested in the recreation allowance.

However, as much as $82 \%$ of employees did not receive information about the possibility of receiving a recreational allowance from their employer.

Of the $18 \%$ of employees who were given information on the possibility of a recreation allowance:

$51 \%$ of employees have already received detailed instructions on how to claim the allowance 
Figure 1. Have you received detailed instructions / guidance how to apply for your allowance?

Dostali ste už podrobné inštrukcie / postup ako uplatnit váš nárok na príspevok?

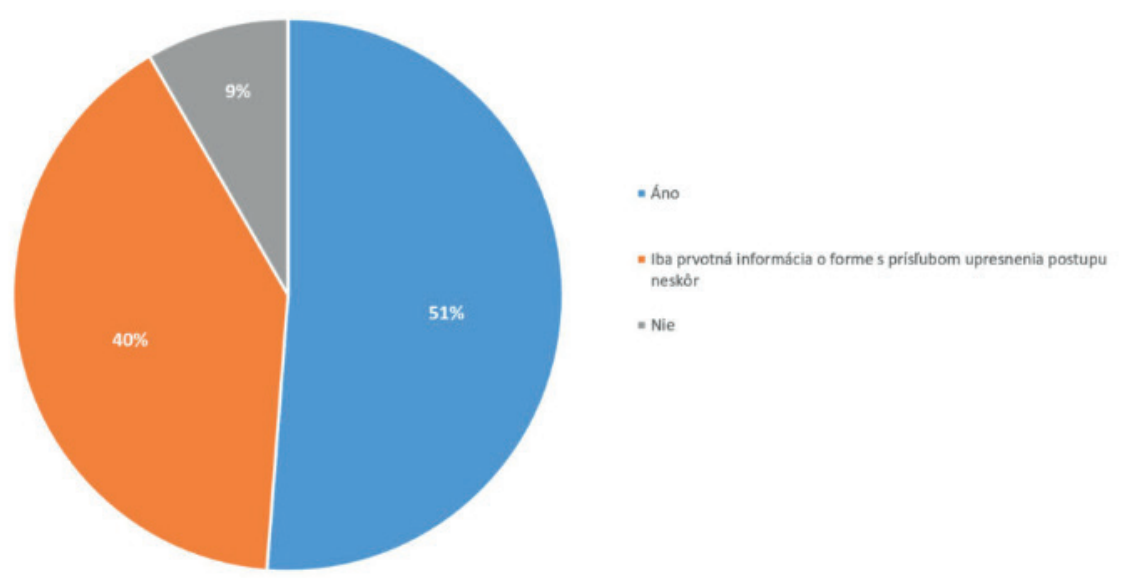

Source: ZDROJ

$40 \%$ of employees received only initial information on the use of the recreation allowance with the promise of further information later

9\% of employees said they have not yet received detailed instructions.

Of the surveyed employees:

$46 \%$ of staff plans to use the allowance for multiple recreations

Figure 2. Do you prefer to use the allowance at once or to divide it into multiple recreations?

Preferuje využit' príspevok zamestnávatel'a jednorázovo alebo na viac pobytov?

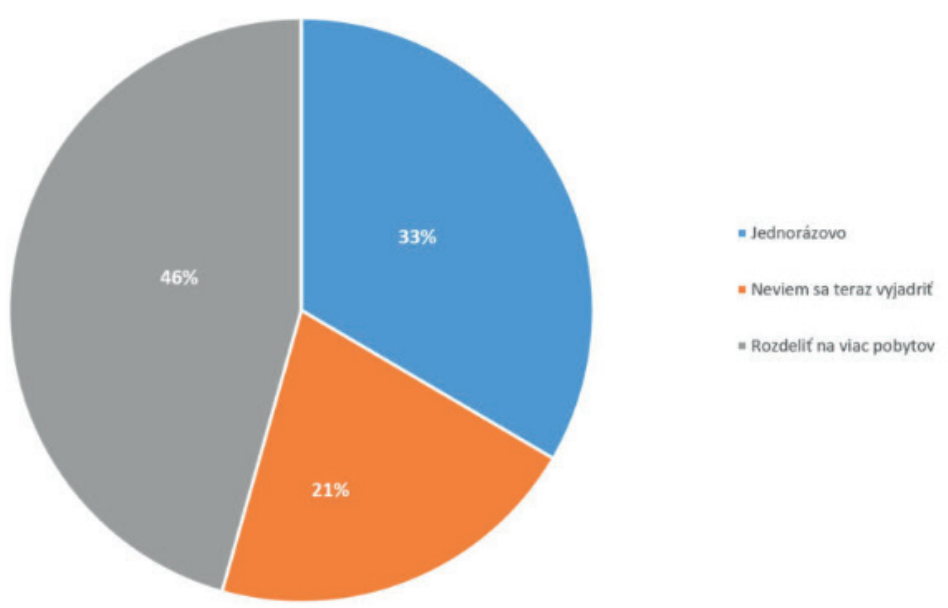

Source: ZDROJ

$79 \%$ of respondents is planning to use the maximum value of the allowance from the employer (275€) 
Of the total of 355 employers:

$\checkmark 48 \%$ of companies approve a new statutory benefit for employees, 35\% approve, but have some reservations. $17 \%$ of employers do not approve the statutory benefit.

Figure 3. How do you perceive this statutory employee benefit?

Ako vnímate tento zo zákona povinný benefit pre zamestnancov?

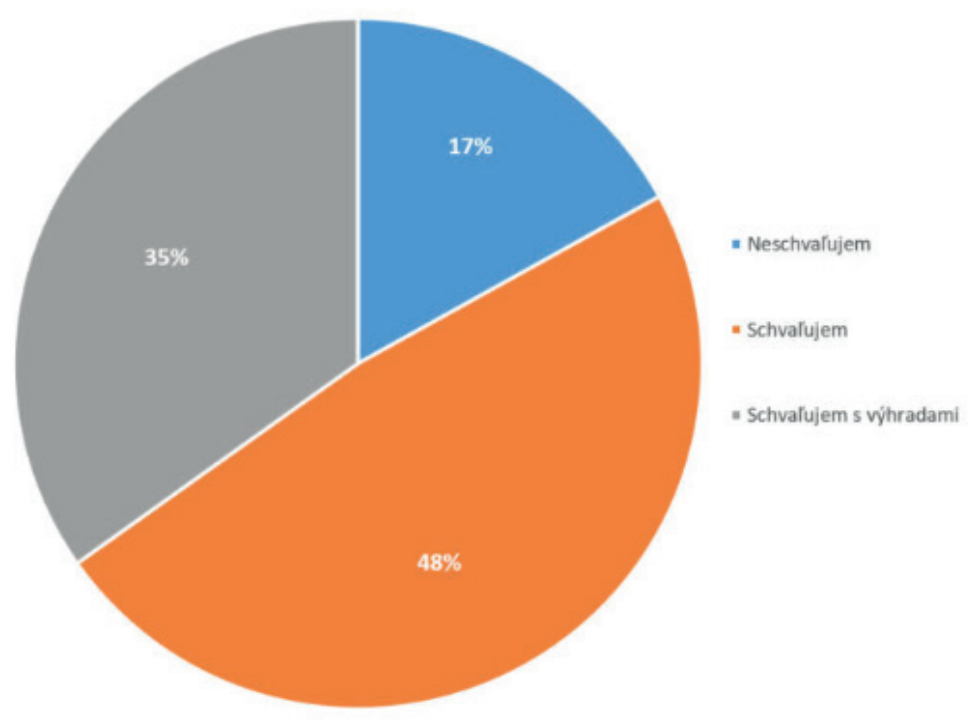

Source: ZDROJ

$\checkmark 66 \%$ of the surveyed companies employ 50 or more employees.

- $68 \%$ of companies employing 49 or fewer employees plan to provide this benefit on a voluntary basis, even if the law does not oblige them to.

$\checkmark 33 \%$ of all employers surveyed plans to provide benefits beyond the law, e.g. to employees who are employed for less than 2 years.

$\checkmark 76 \%$ of employers have already dealt with the form of recreation allowance, while $62 \%$ of employers prefer to reimburse accounting documents delivered to them by employees. Only $13 \%$ of employers plan to provide electronic recreational vouchers. 
Figure 4. In which way do you plan to implement the allowance for the employees?

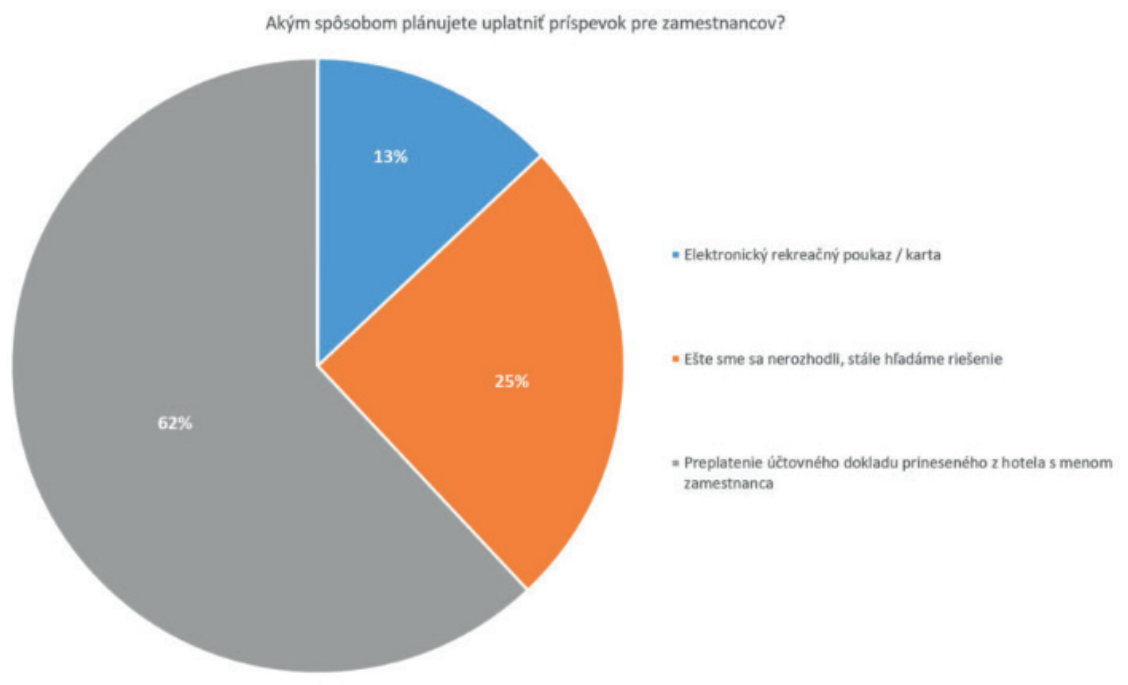

Source: ZDROJ

$\checkmark 36 \%$ of surveyed employers estimates that the number of employees who will use the allowance for recreation will exceed $50 \%$.

\section{Conclusion}

The paper has analysed the aspects, motives, conditions and possibilities of usage of newly legally established allowance for recreation for companies with over 49 employees, that was passed by Slovak national Council with effect from 1st of January 2019. The data from a survey conducted on 2723 employees and 355 employers shown that there are still some gaps in the field of awareness about this newly implemented allowance. Due to this we recommend continuing with raising awareness of employees about the possibility of receiving this allowance. From the point of view of employers we are satisfied with positive reception of the new law, allowance and its terms, that is confirmed by will of subjects with less than 50 employees to provide these benefits as well and to provide them to employees who do not fulfil the requirement of 2 year employment as well. 


\section{References}

\section{Books:}

Gruber, J. (2011). Public finance and public policy, New York, Macmillan.

Rosen, Harvey S. (1992). Public finance, Boston, McGraw-Hill/Irwin.

Schultzová, A. et. al. (2007). Public finance, Bratislava, Ekonóm.

Sivák, R. et al. (2007). Verejné financie, Bratislava, lura Edition.

\section{Internet Sources:}

Daňové centrum. (2019). Usmernenie k príspevkom na rekreáciu s riešenými praktickými príkladmi, Link: https://www.danovecentrum.sk/aktuality/usmernenie-k-prispevkom-narekreaciu-aktualita-dc-3-2019.htm(accessed 22.03.2019)

ResearchGate. (2002). Public Finance: Essay for the Encyclopedia of Public Choice, Link: https://www.researchgate.net/publication/24116809_Public_Finance_Essay_for_the_ Encyclopedia_of_Public_Choice (accessed 20.03.2019)

Najpravo. (2018). Príspevok na rekreáciu zamestnancov, Link: https://www.najpravo.sk/clanky/ prispevok-na-rekreaciu-zamestnancov.html (accessed 19.12.2018)

Prezident. (2018). Reaction of the president on act 91/2010 Coll. on promotion of tourism. Link: https://www.prezident.sk/upload-files/46120.pdf (accessed 08.11.2018)

Zl'avomat. (2019). Výsledky prieskumu o rekreačných poukazoch, Link: https://magazin.zlavomat. sk/novinky/vysledky-prieskumu-o-rekreacnych-poukazoch/ (accessed 17.01.2019)

Trend. (2019). Rekreačné poukazy: Pre živnostníka platia také pravidlá ako pre zamestnanca, Link: https://www.etrend.sk/podnikanie/rekreacne-poukazy-pre-zivnostnika-platia-takepravidla-ako-pre-zamestnanca.html (accessed 09.01.2019)

Zl'avomat. (2019). Nečakajte na rekreačné poukazy - príspevok na dovolenku od zamestnávatel'a môžete využit' ihned'!, Link: https://magazin.zlavomat.sk/novinky/rekreacne-poukazyprispevok-na-dovolenku-zamestnavatel-rekreacia (accessed 15.01.2019)

Mzdové účtovníctvo a personalistika. (2018). Rekreačné poukazy pre zamestnancov v roku 2019. Link: https://www.mup.sk/33/rekreacne-poukazy-pre-zamestnancov-v-roku-2019-uniqu eiduchxzASYZNYgvzA9h2vZFVOh1c70In_j9mbKTrAPMMA/(accessed 11.12.2018)

Odborový zväz pracovníkov školstva a vedy na Slovensku. (2019). Bude štát dotovat' príspevky na rekreácie?, Link: https://www.ozpsav.sk/sk/Aktuality/udalosti-oznamy/bude-stat-dotovatprispevky-na-rekreacie-.alej (accessed 05.02.2019) 